\title{
Alfalfa forage production under solid-set sprinkler irrigation in a semiarid
} climate

Jose Cavero ${ }^{\mathrm{a},{ }^{\star},}$, Jose M. Faci ${ }^{\mathrm{b}}$, Eva T. Medina ${ }^{\mathrm{a}}$, Antonio Martínez-Cob ${ }^{\mathrm{a}, \mathrm{c}}$

${ }^{a}$ Departamento de Suelo y Agua, Estación Experimental de Aula Dei (CSIC), Avda. Montañana 1005, 50059 Zaragoza, Spain.

${ }^{\mathrm{b}}$ Unidad de Suelos y Riegos (Unidad Asociada EEAD-CSIC), Centro de Investigación y Tecnología Agroalimentaria (CITA-DGA), Avda. Montañana 930, 50059 Zaragoza, Spain.

${ }^{c}$ Dr. A. Martínez-Cob passed away during this research.

${ }^{*}$ Corresponding author.

E-mail address: jcavero@eead.csic.es (J. Cavero)

$$
\begin{aligned}
& \text { ABSTRACT } \\
& \text { Under sprinkler irrigation, local environmental conditions have an } \\
& \text { important influence on irrigation water losses, plant physiological changes and } \\
& \text { uniformity of irrigation, leading to different crop water production functions. We } \\
& \text { studied during three years the effect of irrigation depth on the plant growth, } \\
& \text { forage yield and } \mathrm{N} \text { content, evapotranspiration and water use efficiency of an } \\
& \text { alfalfa (Medicago sativa L.) crop irrigated with a commercial solid-set sprinkler } \\
& \text { system in a semiarid Mediterranean climate. Six irrigation treatments were } \\
& \text { tested: } 55 \%, 75 \%, 85 \%, 100 \%, 115 \% \text { and } 130 \% \text { of the theoretical crop irrigation } \\
& \text { requirement }\left(\mathrm{CIR}_{\mathrm{t}}\right) \text {, calculated without considering water losses or non- }
\end{aligned}
$$


1 uniformity. The seasonal irrigation amount applied at the $100 \%$ of $\mathrm{CIR}_{\mathrm{t}}$ ranged

2 from 598 to $786 \mathrm{~mm}$. The intercepted photosynthetically active radiation

3 increased as the irrigation applied increased until the $115 \%$ of $\mathrm{CIR}_{\mathrm{t}}$. Plant

4 height at harvest linearly increased as the irrigation applied increased until the

$5 \quad 130 \%$ of $\mathrm{CIR}_{\mathrm{t}}$ in two years. The maximum alfalfa forage yield was lower the first

6 year $\left(17 \mathrm{Mg} \mathrm{ha}^{-1}\right)$ than in the two following years $\left(20-22 \mathrm{Mg} \mathrm{ha}^{-1}\right)$. The alfalfa

7 forage yield increased linearly as the irrigation applied increased the first year of

8 the experiment, but in the following two years this increase occurred until the

9 irrigation applied was $115 \%$ of $\mathrm{CIR}_{\mathrm{t}}$. The $\mathrm{N}$ content of alfalfa linearly decreased

10 as the irrigation applied increased. The relationship between alfalfa forage yield

11 and evapotranspiration was linear until the $115 \%$ of $\mathrm{CIR}_{t}$ all years. The WUE of

12 alfalfa was lower the first year of the experiment and was not affected by the

13 irrigation applied in the rainiest year, but linearly increased as the irrigation

14 applied increased up to $115 \%$ of $\mathrm{CIR}_{\mathrm{t}}$ in the other two years. Considering yield

15 and quality ( $\mathrm{N}$ content) of alfalfa forage and WUE, sprinkler irrigation with a

16 solid-set system must be increased by $15 \%$ over the $\mathrm{CIR}_{\mathrm{t}}$ to optimize alfalfa

17 forage production under the climatic conditions of the Ebro valley.

20 Keywords: Alfalfa; Semiarid; Sprinkler irrigation; Water use efficiency

21 Abbreviations: $\mathrm{CIR}_{\mathrm{t}}$, theoretical crop irrigation requirement; $\mathrm{ETo}$, reference 22 evapotranspiration; ETc, crop evapotranspiration; GMT, greenwich mean time;

23 PAR, photosynthetically active radiation; WUE, water use efficiency. 


\section{1- INTRODUCTION}

Alfalfa for forage production is a main irrigated field crop in arid and semiarid areas (Abdul-Jabbar, 1985). In the Ebro valley (Spain), the highly calcareous soils and the long free frost period allow to obtain high yields (> 16 $\mathrm{Mg} \mathrm{ha}^{-1}$ ), making alfalfa the highest user of irrigation water (Salvador et al., 2011). The alfalfa acreage in the Ebro valley is around 150.000 ha (MAGRAMA, 2016).

In the last decades modernization of irrigation districts in the Ebro valley river have resulted in the replacement of around half of the acreage from flood irrigation to sprinkler irrigation due to increased yields, decreased requirement and cost of labour and increased economic benefit (Playan and Mateos, 2006; Lecina et al., 2010). High energy costs and regionally occurring shortages of water necessitate the development of adequate crop water production functions. Alfalfa and maize are the main irrigated field crops in the Ebro valley. The response of maize to irrigation has been studied in the semiarid climate of this region (Cosculluela and Faci, 1992; Farre and Faci, 2006), but similar studies are not available for alfalfa, particularly under solid-set sprinkler irrigation, the technology of choice for irrigation modernization projects in the valley. Knowledge of the effect of limiting water on yield allows appropriate economic decisions to be made when resources are limiting.

Sprinkler irrigation allows more flexible irrigation scheduling compared to traditional flood irrigation. However, some water is lost through evaporation at each sprinkler irrigation event. These losses are higher at daytime irrigation events than at nighttime irrigation events (Cavero et al., 2008; Playán et al., 2005; Urrego-Pereira et al., 2013a,b). In the case of alfalfa sprinkler irrigation 
1 evaporation losses ranged from $4 \%$ at nighttime to $10 \%$ at daytime (Cavero et

2 al., 2016; Stambouli et al., 2013). The irrigation water evaporated during the

3 sprinkler irrigation modifies the microclimate of the irrigated area (decrease of

$4 \quad$ VPD and temperature of the air) during the irrigation event and 2 to 3 hours

5 after the irrigation event (Cavero et al., 2009; Cavero et al., 2016; Tolk et al.,

6 1995; Urrego-Pereira et al., 2013a,b). These changes are more relevant during

7 daytime irrigation, causing some physiological changes in the plants. In the

8 case of alfalfa a decrease of crop transpiration (Stambouli et al., 2013) and crop

9 canopy temperature (Cavero et al., 2016; Stambouli et al., 2013), and a slight

10 increase of net photosynthesis have been found (Urrego-Pereira et al., 2013c).

11 Another relevant difference between flood irrigation and sprinkler irrigation is

12 that the distribution uniformity of water in sprinkler irrigation decreases as the

13 wind speed increases (Dechmi et al., 2003; Seginer et al., 1991; Tarjuelo et al., 14 1999).

15 Thus, the local environmental conditions can have an important influence

16 on sprinkler irrigation water losses, plant physiological changes and uniformity

17 of irrigation, leading to different crop water production functions. In this sense,

18 Cavero et al. (2016) found that sprinkler irrigation time of the day (daytime

19 versus nighttime) did not affect alfalfa forage yield in the Ebro valley, although

20 at daytime water losses were higher and irrigation uniformity was slightly lower.

21 Montazar and Sadeghi (2008) found that alfalfa forage yield depended on both

22 the applied water and the sprinkler water uniformity but that was more sensitive

23 to the variations in applied water than to the variations in sprinkler water

24 uniformity. 
A number of research works have focused on the relationship between

2 irrigation depth and alfalfa yield (Carter and Sheaffer, 1983; Grimes et al., 1992;

3 Retta and Hanks, 1980; Sammis, 1981; Shani and Dudley, 2001; Smeal et al.,

4 1992; Peel et al., 2004; Undersander, 1987). Most of them have been

5 performed with the single sprinkler line source system, while others have used

6 surface irrigation (Carter and Sheaffer, 1983). However, information is not

7 available on the application of varying irrigation depths with a commercial solid-

8 set system in large plots $(18 \times 18 \mathrm{~m})$, in which microclimatic and crop

9 physiological changes, and irrigation uniformity can affect alfalfa forage

10 production. Thus, the objective of this research was to study the effect of

11 irrigation depth on the alfalfa forage yield and quality and on the water use

12 efficiency using a commercial solid-set sprinkler irrigation system in the

13 semiarid conditions of the Ebro valley.

2 ha field irrigated with a solid-set sprinkler system, located at Zaragoza, Spain $\left(41^{\circ} 43^{\prime} \mathrm{N}, 0^{\circ} 48^{\prime} \mathrm{W}, 225 \mathrm{~m}\right.$ altitude). The climate is Mediterranean semiarid with

20 long-term annual averages of $14.1^{\circ} \mathrm{C}$ for air temperature, $298 \mathrm{~mm}$ for 21 precipitation, and $1243 \mathrm{~mm}$ for grass reference crop evapotranspiration (ETo).

22 The soil is clay loam and classified as Typic Xerofluvent (Table 1).

\section{2- Experimental layout}

The experimental field was divided in twelve irrigation sectors which were

25 irrigated independently by four sprinklers each (Fig. 1). The borders of the field 
1 were irrigated independently of the main twelve irrigation sectors. The sprinkler

2 spacing was a square of $18 \mathrm{~m} \times 18 \mathrm{~m}$, as generally used in commercial fields in

3 the area. The impact sprinkler (RC-130, Riegos Costa, Lérida, Spain) has a

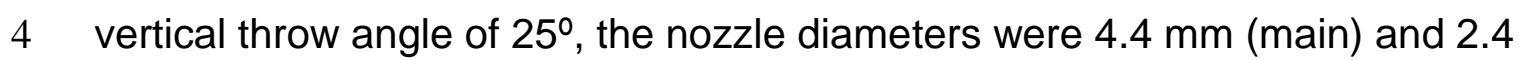

$5 \mathrm{~mm}$ (auxiliary), and the nozzle height was $2.50 \mathrm{~m}$ above the soil surface. The

6 operating pressure was kept constant at $0.3 \mathrm{MPa}$ with a hydraulic pressure

7 control valve. Sprinkler application rate was $5 \mathrm{~mm} \mathrm{~h}^{-1}$ and the wetted radius was

$815 \mathrm{~m}$. The irrigation volume was measured with a flow meter (Woltman WP).

Alfalfa cv. Aragón was planted on 20 Sept. 2011 at $33 \mathrm{~kg} \mathrm{ha}^{-1}$. The

10 previous crop was wheat (Triticum aestivum L.). Sprinkler irrigation was applied

11 the following day after planting and during Sept.-Oct. at 5 to $10 \mathrm{~mm}$ rates to

12 promote the emergence of alfalfa. A total of 14 irrigation events and $105 \mathrm{~mm}$

13 were applied. Fertilization consisted of $200 \mathrm{~kg} \mathrm{ha}^{-1} \mathrm{P}_{2} \mathrm{O}_{5}$, and $200 \mathrm{~kg} \mathrm{ha}^{-1} \mathrm{~K}_{2} \mathrm{O}$

14 applied on March every year. Pests control was carried out following the best

15 management practices of the area. To control weeds, imazamox at $0.5 \mathrm{~kg}$ a.i.

$16 \mathrm{ha}^{-1}$ was applied on February 2013 and metribuzin at $0.52 \mathrm{~kg}$ a.i. ha ${ }^{-1}$ was

17 applied on January 2014.

\section{2-3- Irrigation treatments}

The meteorological data recorded at a weather station over grass located

$201 \mathrm{~km}$ southwest from the experimental field were used to compute the reference

$21 \mathrm{ET}_{0}$ using the FAO Penman-Monteith method (Allen et al., 1998). Crop

22 coefficients $\left(\mathrm{K}_{\mathrm{c}}\right)$ were calculated as a function of thermal time considering the

23 duration of the four phases proposed by Allen et al. (1998) and the Kc initial

24 (0.4), midterm (1.22) and final (1.17) values according to the meteorological

25 conditions of the location of the experiment (Martínez-Cob and García-Vera, 
1 2004). Thermal time was computed as the cumulative daily difference between

2 daily mean air temperature and a basal air temperature of $6^{\circ} \mathrm{C}$ (Breazele et al.,

3 1999; Sharrat et al., 1989) and considering a thermal time of $360^{\circ} \mathrm{Cday}$ for the

4 first harvest and $500^{\circ} \mathrm{Cday}$ for the rest of the harvests. Daily crop

5 evapotranspiration of alfalfa $\left(E T_{c}\right)$ was then obtained as the $E T_{0}$ multiplied by

6 the $\mathrm{K}_{\mathrm{c}}$. Irrigation water electrical conductivity ranged from 0.4 to $0.6 \mathrm{dS} \mathrm{m}^{-1}$,

7 which is not limiting for alfalfa growth (Isla and Aragües, 2009).

The theoretical crop irrigation requirements $\left(\mathrm{CIR}_{\mathrm{t}}\right)$ were calculated weekly

9 as the difference between $\mathrm{ET}_{\mathrm{c}}$ and the effective precipitation (estimated as $75 \%$

10 of precipitation (Dastane, 1978)). The initial soil water content above the wilting

11 point at the 0-1.6 $\mathrm{m}$ depth was considered as available for the crop and

12 subtracted from $\mathrm{CIR}_{\mathrm{t}}$ at the beginning of the crop season. The sprinkler

13 irrigation requirement could be different from the theoretical because of wind

14 drift and evaporation losses, non-uniform irrigation, plant physiological changes

15 during the irrigation events and soil characteristics. In order to obtain a crop

16 water production function it is necessary to test a wide range of irrigation

17 treatments. Thus, six irrigation treatments were tested: 55\% (155), 75\% (I75),

$1885 \%$ (I85), $100 \%$ (I100), $115 \%$ (I115) and 130\% (I130) of ClR $\mathrm{R}_{\mathrm{t}}$ Sprinkler

19 irrigation was applied at daytime, generally starting at 900 to 1100 Greenwich

20 Mean Time (GMT). The weekly irrigation amount was applied in one to three

21 irrigation events that lasted 1 to $6 \mathrm{~h}$ depending on the irrigation treatment. The

22 experimental plot was the area surrounded by the four sprinklers of each

23 irrigation sector (Fig. 1) and has an area of $324 \mathrm{~m}^{2}$. The area outside was not

24 considered because it received water from different irrigation sectors. The

25 experimental design was randomized with two replicates per treatment. 


\section{4- Soil water content}

One soil core of $0.05 \mathrm{~m}$ diameter was taken from the centre of each experimental plot on September 2011 to a depth of $1.8 \mathrm{~m}$ at $0.30 \mathrm{~m}$ intervals and the gravimetric soil water content was determined.

On March 2012 two plastic tubes of 1.80 m length were installed in the soil of each experimental plot. One was located centred in the $18 \mathrm{~m} \times 18 \mathrm{~m}$ square of the plot and the other at $4 \mathrm{~m}$ of one corner (Fig. 1). The gravimetric soil water content was determined at $0.3 \mathrm{~m}$ intervals in the soil cores taken for the installation of the plastic tubes. A capacitance sensor (Diviner 2000, Sentek

Pty Ltd, Stepney, Australia) of $1.60 \mathrm{~m}$ length was used to take measurements every $0.10 \mathrm{~m}$. In order to calibrate the capacitance probe, five $1.80 \mathrm{~m}$ length plastic tubes were located close to the main plots. On 20 May 2012 the capacitance probe was used to obtain measurements of the five tubes every $0.10 \mathrm{~m}$. Immediately after, undisturbed soil samples were taken to determine the volumetric soil water content. A linear regression with a $r^{2}$ of 0.85 was found between the capacitance probe measurements and the volumetric soil water content determined in the undisturbed soil samples. The RMSE between the actual water content of the undisturbed soil samples and that estimated through the calibration equation was $0.017(\mathrm{~m} / \mathrm{m})$.

During the crop season measurements of soil water content with the capacitance probe were made every two-three weeks. The average values of the soil water content measured in the two tubes installed in each experimental plot were used for statistical analysis. 


\section{5- Intercepted photosynthetically active radiation and plant height} The percentage of photosynthetically active radiation (PAR) intercepted by the alfalfa crop was determined the day before each harvest using a 1-m length ceptometer (Delta-T Sunscan) and a PAR sensor (Delta-T BF3). All the measurements were taken around 1100 GMT. The PAR sensor continuously measured the incoming PAR above the crop canopy every $5 \mathrm{~s}$. The transmitted PAR below the canopy was measured with the ceptometer in 10 spots of each experimental plot. The fraction of the PAR intercepted by the alfalfa crop at each of the 10 sampling spots was calculated as the difference between the PAR sensor reading (above the crop) and the simultaneous ceptometer reading (below the crop). The average intercepted PAR at each experimental plot was obtained.

The day before each alfalfa harvest plant height was measured at 10 spots walking two diagonals within each experimental plot. Plant height was measured with a wood ruler as the distance between the soil surface and the top of the canopy. The average value of the 10 spots at each experimental plot was used for statistical analysis.

\section{6- Alfalfa forage yield and quality ( $\mathrm{N}$ content)}

All tillage operations were made with commercial equipment. Six alfalfa harvests were performed each year. A commercial cutting machine 3-m wide was used to cut the alfalfa at $7 \mathrm{~cm}$ above the soil surface. After cutting, the alfalfa was allowed to dry for one day in the field and then the forage in two samples $(2-\mathrm{m} \times 6-\mathrm{m})$ was taken at each experimental plot. The alfalfa forage of each sample was weighted and a subsample was taken and dried at $60{ }^{\circ} \mathrm{C}$ to determine the moisture content. Alfalfa quality was determined by means of its 
$1 \mathrm{~N}$ content (Putnam et al., 2008). Thus, once dried, the subsample was grinded

2 and analysed to determine the $\mathrm{N}$ content by combustion (TruSpec CN, LECO,

3 St. Joseph, MI, USA). The forage yield and $\mathrm{N}$ content average values of the two

4 samples of each experimental plot were used for statistical analysis. The rest of

5 the alfalfa was left in the field for sun drying after cutting during three days and

6 then removed and transported to a dehydration plant. The $\mathrm{N}$ uptake was

7 obtained from the forage yield and its $\mathrm{N}$ content.

\section{7- Water use efficiency}

The water balance was used to calculate the actual alfalfa evapotranspiration $\left(E T_{w b}\right)$ at each plot during each season. Irrigation applied (I), rainfall $(R)$ and the change in soil water content between the closest measurement date to the start of alfalfa growth at winter time (late February) $\left(S W_{i}\right)$ and to the last harvest cycle (October) were used $\left(S W_{\mathrm{f}}\right)$. Soil water content data of the deepest profile suggested that water did not leach below the measurement depth (1.60 m) (Figure 2), because it was well below the field capacity and without relevant changes during the irrigation seasons. Thus, deep percolation was considered negligible, and the equation used to calculate the actual alfalfa evapotranspiration was:

$E T_{w b}=S W_{i}-S W_{f}+\mathrm{I}+\mathrm{R}$

The water use efficiency (WUE) was calculated for each plot as the ratio between the seasonal alfalfa forage yield and the $E T_{w b}$.

\section{8- Statistical analysis}

The effect of irrigation treatment on soil water content, plant height, alfalfa forage yield, $\mathrm{N}$ content, $\mathrm{N}$ uptake, seasonal actual alfalfa evapotranspiration and WUE were analysed by linear regression. 


\section{3- RESULTS}

\section{1- Weather, irrigation applied and characteristics of irrigation}

events

The main period of alfalfa growth at the site begins on March and finishes at mid October. Average daily temperature was similar in 2012 and 2014, but lower in 2013 (Table 2). The average daily wind speed was similar all years. Average solar radiation was similar in 2012 and 2014, but lower in 2013. Thus, the ETo was higher in 2012 and 2014 than in 2013. Rainfall was highest in 2013 and lowest in 2012.

The soil available water before starting the first irrigation season (2012) was $10 \mathrm{~mm}$ (Figure 2, Table 3). The following years the soil available water before starting the irrigation season was variable and, in general, increased as the irrigation treatment applied more water (Table 3). The seasonal irrigation amount applied at the 1100 treatment ranged from 598 to 786 (Table 3). The lowest irrigated treatment received around $400 \mathrm{~mm}$, while the highest irrigated treatment received between $735 \mathrm{~mm}$ and $1028 \mathrm{~mm}$.

The mean water depth applied per irrigation event generally increased as the irrigation treatment increased (Table 4). The average wind speed during the irrigation events ranged from 2.3 to $2.7 \mathrm{~m} \mathrm{~s}^{-1}$ and slightly increased as the irrigation treatment increased (Table 4).

\section{2- Soil water content}

The soil water content was close to the wilting point in the $0-1.6 \mathrm{~m}$ depth before starting the irrigation the first year of the experiment (2012) (Fig. 2).

During the irrigation season the soil water content was always lower than the field capacity (Fig. 2) and increased as the irrigation applied increased (Fig. 2 
1 and 3). The increase was more evident in the irrigation treatments that received

2 at least $100 \%$ of the $\mathrm{CIR}_{\mathrm{t}}$ (Fig. 2 and 3 ). Soil water changes occurred mainly

3 within the 0-1.2 $\mathrm{m}$ soil layer (Fig. 2). At the deepest soil profile (1.2-1.6 m) few

4 changes were observed during the irrigation season each year (Fig. 2). Before

5 the start of the second irrigation season (2013) the soil water content was below

6 the wilting point in the irrigation treatments that received less water (Fig. 2).

\section{3- Alfalfa intercepted PAR and height}

The intercepted PAR increased as the irrigation applied increased until the 1115 treatment (Fig. 4). Increasing the irrigation applied further did not increase the intercepted PAR. Decreasing the irrigation applied below the 170 resulted in a strong decrease of intercepted PAR. Similar average intercepted PAR values (92- $97 \%$ ) were found the three years of the experiment for treatments that applied irrigation at $100 \%$ of $\mathrm{CIR}_{t}$ or higher (Fig. 4). However, when irrigation applied was lower than $100 \%$ of $\mathrm{CIR}_{\mathrm{t}}$ there were strong differences of intercepted PAR between years and these differences were greater as the irrigation applied decreased.

Plant height linearly increased as the irrigation applied increased until the I130 treatment in two years (2012 and 2014) (Fig. 5). In 2013, plant height linearly increased as the irrigation applied increased until the 1115, but applying more water did not increase plant height.

\section{4- Alfalfa forage yield, quality ( $\mathrm{N}$ content) and $\mathrm{N}$ uptake}

In the first year of the experiment (2012), the annual alfalfa forage yield linearly increased as the irrigation water applied increased (Fig. 6, Table 5). However, the following two years the annual alfalfa forage yield linearly increased as the irrigation applied increased up to the 1115 treatment. These 
1 years, increasing the irrigation applied at the $130 \%$ of $\mathrm{CIR}_{t}$ did not change the

2 alfalfa forage yield compared to the treatment that applied $115 \%$ of $\mathrm{CIR}_{\mathrm{t}}$. When

3 analysing the yield at each harvest cycle the results were similar to the annual

4 forage yield, but in some harvest cycles when rainfall was high the effect of

$5 \quad$ irrigation treatment on forage yield was lower (Table 5).

6 The first year of the experiment (2012) the annual yield weighted average

$7 \mathrm{~N}$ content of the alfalfa forage linearly decreased as the irrigation water applied

8 increased above $85 \%$ of $\mathrm{CIR}_{\mathrm{t}}$ (Fig. 7). However, in the following two years (2013

9 and 2014), the $\mathrm{N}$ content of the alfalfa forage linearly decreased as the irrigation

10 water applied increased since the lowest irrigated treatment (I55). The N

11 content was higher than $3 \%$ in all treatments, which is considered as good

12 (Putnam et al., 2008), except on I130 in 2012.

13 The first year of the experiment the $\mathrm{N}$ uptake of alfalfa increased linearly

14 as the irrigation applied increased (Fig. 8). However, in the following two years

15 the $\mathrm{N}$ uptake of alfalfa increased linearly as the irrigation applied increased only

16 up to the 1115 treatment. These years increasing the irrigation applied at the

$17130 \%$ of $\mathrm{CIR}_{\mathrm{t}}$ slightly decreased the $\mathrm{N}$ uptake of alfalfa compared to the

18 treatment that applied $115 \%$ of $\mathrm{CIR}_{\mathrm{t}}$.

\section{5- Alfalfa evapotranspiration and WUE}

The $\mathrm{ET}_{\text {wb }}$ ranged from 511 to $1057 \mathrm{~mm}$ and increased linearly with the

21 irrigation applied (Table 6). The $\mathrm{ET}_{\text {wb }}$ of the $\mathrm{I} 100$ treatment was very close to the

22 theoretical alfalfa evapotranspiration the three years. The mean $\mathrm{ET}_{\mathrm{wb}}$ of

23 irrigation treatments that applied less water decreased to 0.89 (I85), 0.77 (I70) and 0.66 (155) compared to the 1100 treatment, but some variation occurred 
1 between years. Application of irrigation water above the 1100 treatment

2 increased the $\mathrm{ET}_{\text {wb }}$ by $8 \%(\mathrm{I115})$ and $15 \%$ (I130) in average.

In the first year of the experiment, the forage yield increased linearly as

4 the evapotranspiration of alfalfa increased (Fig. 9). However, in the following

5 two years the forage yield increased linearly as the evapotranspiration of alfalfa

6 increased until the $\mathrm{I115}$ treatment. These years, applying more water in the I130

7 treatment resulted in a higher evapotranspiration but not in a higher yield (Fig.

$89)$.

At each irrigation treatment, the WUE of alfalfa was, in general, lower the

10 first year of the experiment (Fig. 10) as compared to the following years. In the

11 second and third years of the alfalfa crop the WUE was similar for those

12 treatments that received $\geq 100 \%$ of $\mathrm{CIR}_{\mathrm{t}}$, but interyear differences of WUE

13 occurred in the irrigation treatments that received less water.

In the first year of the experiment the WUE linearly increased as the

15 irrigation water applied increased (Fig. 10). However, if the lowest irrigation

16 treatment was removed from the regression analysis, the WUE was not affected

17 by the irrigation water applied. In the second year of the experiment (2013) the

18 WUE was not affected by the irrigation water applied. In the last year of the

19 experiment (2014) the WUE linearly increased as the irrigation water applied

20 increased up to the 1115 treatment. At the highest WUE, $59 \mathrm{~mm}$ of ET were

21 needed to obtain $1 \mathrm{Mg} \mathrm{ha}^{-1}$ of alfalfa forage the first year of the experiment, but

2242 and $45 \mathrm{~mm}$ were needed in the following two years. 


\section{4- DISCUSSION}

The maximum alfalfa forage yield obtained each year, $17 \mathrm{Mg} \mathrm{ha}^{-1}$ in the first year and $20-22 \mathrm{Mg} \mathrm{ha}^{-1}$ in the following years, is in the high range of reported from semiarid areas (Grimes et al., 1992; Lindenmayer et al., 2011; Lloveras et al., 2008; Sheaffer et al., 1988; Smeal et al., 1992).

Soil water content data at the deepest soil profile (1.2-1.6 m) showed little variation, suggesting that leaching of water did not occur below this soil profile. Although it is reported that alfalfa can withdraw water below this depth (Dardanelli et al., 1997; Grimes et al., 1992), many works have found that under irrigation most water is taken up from the shallower soil profiles (Kipnist et al., 1989; Sheaffer et al., 1988).

The first year of the experiment the alfalfa forage yield increased linearly as the irrigation applied increased as found by others (Bauder et al., 1978; Lindenmayer et al., 2011; Peel et al., 2004; Retta and Hanks, 1980). However, in the following years this increase of forage yield occurred until the 1115 treatment. The yield response to higher levels of irrigation in the first year could be related to the lower available soil water at the start of the experiment and to the lower development of roots (Bai and Li, 2004; Lindenmayer et al., 2011). The lack of response to irrigation at high irrigation depths has been found by others in alfalfa (Carter and Sheaffer, 1983; Donovan and Meek, 1983; Fick et al., 1988; Geerts and Raes, 2009; Montazar and Sadeghi, 2008; Smeal et al., 1992; Snaydon, 1972) and in our experiment was related to the fact that the IPAR did not increase with the highest irrigation depth. Several studies have found that excessive soil moisture due to excess irrigation or rainfall is detrimental to alfalfa growth and to stand persistence (Peterschmidt et al., 1979; 
1 Wahab and Chamblee, 1972), due to lack of $\mathrm{O}_{2}$ in the root zone and to the

2 formation of ethanol and other toxic substances in the roots (Barta, 1980;

3 Christian, 1977; Fick et al., 1988).

The response of crops to irrigation water depends on irrigation efficiency

5 that for sprinkler systems relies both on uniformity of distribution and water

6 losses. Although the irrigation uniformity can affect the alfalfa forage yield

7 (Montazar and Sadeghi, 2008), the wind speed during the experiment was

8 similar to that reported by Cavero et al. (2016) in a nearby experiment where

9 average irrigation uniformity was $85-87 \%$ and seasonal irrigation uniformity was

$1092-94 \%$, so irrigation uniformity was probably high. The slight increase of mean

11 wind speed as the irrigation applied increased was due to the higher duration of

12 the irrigation events because in our area wind speed increases from morning

13 hours until the afternoon (Sanchez et al., 2011), but given its low magnitude

14 they hardly affected differently to the irrigation uniformity of the different

15 irrigation treatments. Our results show that alfalfa evapotranspiration increased

16 by $8 \%$ above the theoretical evapotranspiration when irrigation was applied at

$17115 \%$ of theoretical requirement, which is close to the $10 \%$ of sprinkler irrigation

18 water lost as wind drift and evaporation losses in nearby experiments irrigated

19 similarly (Cavero et al., 2016; Stambouli et al., 2013). This could be the reason

20 why alfalfa forage yield increased all years when irrigation applied was $115 \%$ of

$21 \mathrm{CIR}_{\mathrm{t}}$. However, the further increased evapotranspiration by $15 \%$ above of

22 theoretical found at the highest irrigation treatment only increased alfalfa forage

23 yield the first year, as explained. The highest irrigation applied could increase

24 the soil evaporation component of evapotranspiration after the irrigation events 
1 and also could result in higher water losses by evaporation and drift during the 2 irrigation events.

Plant height had a stronger response to water than forage yield, with two out of three years showing a linear increase as the irrigation applied increased. Increased alfalfa height with increased irrigation depth has been found in other

6 works (Brown and Tanner, 1983; Donovan ad Meek, 1983; Montazar and

7 Sadeghi, 2008), although Donovan ad Meek (1983) did not find differences in plant height when the applied irrigation exceeded the optimum.

Although the $\mathrm{N}$ content of alfalfa was, in general, higher than $3 \%$, the observed decrease of $\mathrm{N}$ content as the irrigation applied increased indicates

11 that a dilution effect occurred, which is in contrast with the fact that $\mathrm{N}$ fixation is

12 more affected by water stress than carbon assimilation (Serraj et al., 1999).

13 However, some authors reported a similar finding (Gifford and Jensen, 1967;

14 Donovan and Meek, 1983), and others found that irrigation depth did not affect

$15 N$ content of alfalfa forage (Carter and Sheaffer, 1983; Snaydon, 1972;

16 Undersander et al., 1987; Vough and Marten, 1971). It is particularly relevant

17 that increasing the irrigation depth to $130 \%$ of $\mathrm{CIR}_{t}$ did not increase yield in two out of three years over the $115 \%$ of $\mathrm{CIR}_{\mathrm{t}}$, but decreased the $\mathrm{N}$ content of alfalfa

19 all years, one of them below 3\%. Rogers (1974) found that when water is

20 applied in excess, the $\mathrm{N}$ content of alfalfa decreased.

The maximum WUE found in the second and third years of the experiment are in the high range of reported WUE (Grimes et al., 1992; Kipnist

23 et al., 1989; Lindenmayer et al., 2011; Sheaffer et al, 1988). A lower WUE the

24 first year of alfalfa crop has also been reported by Lindenmayer et al. (2011),

25 that indicated that this occurred because much of the carbon that is fixed in 
1 photosynthesis in the early years is partitioned to root development and

2 because soil evaporation is higher during the establishment year due low

3 ground cover by the alfalfa crop. As found by Lindenmayer et al. (2011), the

4 WUE decreased as water deficit increased, except in the rainiest year, when

5 WUE of alfalfa was not affected by the irrigation applied, similarly what was

6 found by Bauder et al. (1978). Applying water in excess to alfalfa can decrease

7 the WUE due to increased evapotranspiration but not yield increase (Donovan

8 and Meek, 1983). 
13 the sprinkler irrigation system, that increased evapotranspiration. Considering 14 yield and quality ( $\mathrm{N}$ content) of alfalfa forage and WUE, sprinkler irrigation with a solid-set system must be increased by $15 \%$ over the theoretical requirement 16 to optimize alfalfa forage production under the climatic conditions of the Ebro 17 valley.

\section{5- CONCLUSIONS}

The alfalfa forage yield linearly increased as the sprinkler irrigation applied increased from $55 \%$ to $130 \%$ of the theoretical crop irrigation requirement in the first year of the experiment, but up to $115 \%$ in the following two years. However, alfalfa evapotranspiration linearly increased as the sprinkler irrigation applied increased all years. Although the $\mathrm{N}$ content of alfalfa was, in general, higher than $3 \%$, it decreased as the irrigation applied increased. The WUE of alfalfa was not affected by irrigation in the rainiest year, but increased as the irrigation applied increased up to $115 \%$ of the theoretical crop irrigation requirement in the other years.

The yield response at irrigation rates higher than $100 \%$ of theoretical crop irrigation requirement was related to wind drift and evaporation losses of 


\section{6- ACKNOWLEDGEMENTS}

2 This work was supported by the project AGL2010-21681-C03-01 (Ministerio de

3 Economía y Competitividad) of Spanish Government. We thank M. Izquierdo, J.

4 Gaudó, M. Guillen, M.A. Millán and P. Paniagua for the technical assistance in 5 the field and laboratory. 


\section{7- REFERENCES}

2 Abdul-Jabbar, A.S., Lugg, D.G., Sammis, T.W., Gay, L.W., 1985. Relationships

3 between crop water stress index and alfalfa yield and evapotranspiration. Trans. ASAE 28, 454-461.

Allen, R.G., Pereira, L.S., Raes, D., Smith, M., 1998. Crop evapotranspiration:

6 Guidelines for computing crop water requirements. Irrig. and Drain. Paper 7 56. FAO, Rome.

8 Bai, W.M., Li, L.H., 2003. Effect of irrigation methods and quota on root water Agric. Water Manage. 62, 139-148.

Barta, A.L., 1980. Regrowth and alcohol dehydrogenase activity in waterlogged alfalfa and birdsfoot trefoil. Agron. J. 72, 1017-1020.

Bauder, J.W., Bauer, A., Ramirez, J.M., Cassel, D.K., 1978. Alfalfa water use and production on dryland and irrigated sandy loam. Agron. J. 70, 95-99.

Breazeale, D., Kettle, R., Munk, G., 1999. Using growing degree days for alfalfa production. Fact Sheet 99-7. University of Reno, Nevada.

Brown, P.W., Tanner, C.B., 1983. Alfalfa stem and leaf growth during water stress. Agron. J. 75, 799-805.

Carter, P.R., Sheaffer, C.C., 1983. Alfalfa response to soil water deficits. I. Growth, forage quality, yield, water use, and water-use efficiency. Crop Sci. 23, 669-675.

Cavero, J., Jiménez, L., Puig, M., Faci, J.M., Martínez-Cob, A., 2008. Maize growth and yield under daytime and nighttime solid-set sprinkler irrigation. Agron. J. 100, 1573-1579. 
1 Cavero, J., Faci, J.M., Martínez-Cob, A., 2016. Relevance of sprinkler irrigation

2 time of the day on alfalfa forage production. Agric. Water Manage. 178, 304-

3313

4 Cavero, J., Medina, E.T., Puig, M., Martínez-Cob, A., 2009. Sprinkler irrigation

5 changes maize canopy microclimate and crop water status, transpiration,

6 and temperature. Agron. J. 101, 854-864.

7 Christian, K.R., 1977. Effects of the environment on the growth of alfalfa. Adv.

9 Cosculluela, F., Faci, J.M., 1992. Obtención de la función de producción del

10 maíz (Zea mays L.) respecto al agua mediante una fuente lineal de

11 aspersión. Inv. Agr. Prod. Prot. Veg. 7, 169-194.

12 Dardanelli, J.L., Bachmeier, O.A., Sereno, R., Gil, R., 1997. Rooting depth and

13 soil water extraction patterns of different crops in a silty loam Haplustoll.

$14 \quad$ Field Crops Res. 54, 29-38.

15 Dastane, N.G., 1978. Effective rainfall in irrigated agriculture. Irrig. and Drain.

16 Paper 25. FAO, Rome.

17 Dechmi, F., Playan, E., Cavero, J., Faci, J.M., Martínez-Cob, A., 2003. Wind

18 effects on solid-set sprinkler irrigation depth and yield of maize (Zea mays).

19 Irrig. Sci 22, 67-77.

20 Donovan, T.J., Meek, B.D., 1983. Alfalfa responses to irrigation treatment and

21 environment. Agron. J. 75, 461-464.

22 Farre, I., Faci, J.M., 2006. Comparative response of maize (Zea mays L.) and 23 sorghum (Sorghum bicolor L. Moench) to deficit irrigation in a Mediterranean

24 environment. Agric. Water Manage. 83, 135-143. 
1 Fick, G.W., Holt, D.A., Lugg, D.G., 1988. Environmental physiology and crop

2 growth, in: Hanson, A.A., Barnes, D.K., Hill, R.R. (Eds.), Alfalfa and alfalfa improvement. Agronomy Monograph 29, 163-194. ASA, Madison, WI, USA.

Geerts, S., Raes, D., 2009. Deficit irrigation as an on-farm strategy to maximize crop water productivity in dry areas. Agric. Water Manage. 96, 1275-1284.

6 Gifford, R.O., Jensen, E.H., 1967. Some effects of soil moisture regimes and 7 bulk density on forage quality in the greenhouse. Agron. J. 59, 75-77.

8 Grimes, D.W., Wiley, P.L., Sheesley, W.R., 1992. Alfalfa yield and plant water relations with variable irrigation. Crop Sci. 32, 1381-1387.

Isla, R., Aragües, R., 2009. Response of alfalfa (Medicago sativa L.) to diurnal and nocturnal saline sprinkler irrigations. I: total dry matter and hay quality. Irrig. Sci. 27, 497-505.

Kipnist, T., Vaisman, I., Granoth, I., 1989. Drought stress and alfalfa production in a mediterranean environment. Irrig. Sci. 10, 113-125.

Lecina, S., Isidoro, D., Playén, E., Aragüés, R., 2010. Irrigation modernization and water conservation in Spain: The case of Riegos del Alto Aragón. Agric. Water Manage. 97, 1663-1675.

Lindenmayer, R.B, Hansen, N.C., Brummer, J., Pritchett, J.G., 2011. Deficit irrigation of alfalfa for water-savings in the Great Plains and Intermountain West: a review and analysis of the literature. Agron. J. 103, 45-50.

Lloveras, J., Chocarro, C., Freixes, O., Arqué, E., Moreno, A., Santiveri, F., 2008. Yield, yield components, and forage nutritive value of alfalfa as affected by seeding rate under irrigated conditions. Agron. J. 100, 191-197. 
1 MAGRAMA, 2016. Superficies y producciones anuales de cultivos. Available at

2 http://www.magrama.gob.es/es/estadistica/temas/estadisticas-

3 agrarias/agricultura/superficies-producciones-anuales-cultivos/ (accessed 6 Oct. 2016). Ministerio de Agricultura y Medio Ambiente, Gobierno de España, Madrid, Spain.

6 Martínez-Cob, A., García-Vera, M.A., 2004. Revisión de las necesidades

7 hídricas netas de los cultivos de la cuenca del Ebro. Internal Technical

Peel, M.D., Asay, K.H., Johnson, D.A., Waldron, B.L., 2004. Forage production of sainfoin across and irrigation gradient. Crop Sci. 44, 614-619.

Peterschmidt, N.A., Delaney, R.H., Greene, M.C., 1979. Effects of overirrigation on growth and quality of alfalfa. Agron. J. 71, 752-754.

Playán, E., Mateos, L., 2006. Modernization and optimization of irrigation systems to increase water productivity. Agric. Water Manage. 80, 100-116.

Playán, E., Salvador, R., Faci, J.M., Zapata, N., Martínez-Cob, A., Sanchez, I., 2005. Day and night wind drift and evaporation losses in sprinkler solid-sets and moving laterals. Agric. Water Manage. 76, 139-159.

Putnam, D.H., Robinson, P., DePeters, E., 2008. Forage quality and testing, in: Summers, C.G., Putnam, D.H. (Eds.), Irrigated alfalfa management for Mediterranean and desert zones, Chapter 16, pp. 25. Oakland, Univ. of California. Agricultural and Natural resources publication ํำ 8302 . 
1 Retta, A., Hanks, R.J., 1980. Corn and alfalfa production as influenced by

$2 \quad$ limited irrigation. Irrig. Sci. 1, 135-147.

3 Rogers, V.E., 1974. The response of lucerne cultivars to levels of waterlogging. Australian Journal of Experimental Agriculture 14:520-525.

Salvador, R., Martínez-Cob, A., Cavero, J., Playán, E., 2011. Seasonal on-farm irrigation performance in the Ebro basin (Spain): Crops and irrigation systems. Agric. Water Manage. 98:577-587.

Sammis, T.W., 1981. Yield of alfalfa and cotton as influenced by irrigation. Agron. J. 73, 323-329.

Sanchez, I., Zapata, N., Faci, J.M., Martínez-Cob, A., 2011. The spatial variability of the wind in a sprinkler irrigated district: Implications for irrigation management. Biosystems Engineering 109, 65-76.

Seginer, I., Kantz., D., Nir, D., 1991. The distortion by wind of the distribution patterns of single sprinklers. Agric. Water Manage. 19, 341-359.

Serraj, R., Sinclair, T.R., Purcell, L.C., 1999. Symbiotic $\mathrm{N}_{2}$ fixation response to drought. J. Exp. Botany 50, 143-155.

Shani, U., Dudley, L.M., 2001. Field studies of crop response to water and salt stress. Soil Sci. Soc. Am. J. 65, 1522-1528.

Sharratt, B.S., Sheaffer, C.C., Baker, D.G., 1989. Base temperature for the application of the growing degree day model to field grown alfalfa. Field Crops Res. 21, 95-102.

Sheaffer, C.C., Tanner, C.B., Kirkham, M.B., 1988. Alfalfa water relations and irrigation, in: Hanson, A.A., Barnes, D.K., Hill, R.R. (Eds.), Alfalfa and alfalfa improvement. Agronomy Monograph 29, 373-409. ASA, Madison, WI, USA. 
1 Smeal, D., Gregory, E.J., Arnold, R.N., 1992. Interseasonal variability in the

2 water use-production function of alfalfa. J. Prod. Agric. 5, 576-580.

3 Snaydon, R.W. 1972. The effect of total water supply, and of frequency of application upon Lucerne. II. Chemical composition. Aust. J. Agic. Res. 23, 253-256.

6 Stambouli, T., Martínez-Cob, A., Faci, J.M., Howell, T., Zapata, N., 2013.

$7 \quad$ Sprinkler evaporation losses in alfalfa during solid-set sprinkler irrigation in 8 semiarid areas. Irrig. Sci. 31, 1075-1089.

9 Tarjuelo, J.M., Montero, J., Valiente, M., Honrubia, F., Ortiz, J., 1999. Irrigation

10 uniformity with medium size sprinklers. Part II: Influence of wind and other

11 factors on water distribution. Trans. ASAE 42, 677-689.

12 Tolk, J.A., Howell, T.A., Steiner, J.L., Krieg, D.R., Schneider, A.D., 1995. Role

13 of transpiration suppression by evaporation of intercepted water in improving 14 irrigation efficiency. Irrig. Sci. 16, 89-95.

15 Undersander, D.J., 1987. Alfalfa (Medicago sativa L.) growth response to water 16 and temperature. Irrig. Sci. 8, 23-33.

17 Undersander, D.J., Cole, N.A., Naylor, C.H., 1987. Digestibility and rate of 18 passage by lambs of water-stressed alfalfa. J. of Animal Sci. 64, 1813-1820.

19 Urrego-Pereira, Y., Cavero, J., Medina, E.T., Martínez-Cob, A., 2013a.

20 Microclimatic and physiological changes under a center pivot system

21 irrigating maize. Agric. Water Manage. 119, 19-31.

22 Urrego-Pereira, Y., Martínez-Cob, A., Cavero, J., 2013b. Relevance of sprinkler 23 irrigation time and water losses on maize yield. Agron. J. 105, 845-853. 
1 Urrego-Pereira, Y., Martínez-Cob, A., Fernández, V., Cavero, J., 2013c.

2 Daytime sprinkler irrigation effects on net photosynthesis of maize and 3 alfalfa. Agron. J. 105, 1515-1528.

4 Vough, L.R., Marten, G.C., 1971. Influence of soil moisture and ambient 5 temperature on yield and quality of alfalfa forage. Agron. J. 63, 40-42.

6 Wahab, H.A., Chamblee, S., 1972. Influence of irrigation on the yield and 7 persistence of forage legumes. Agron. J. 64, 713-716. 
1 Figure 1. Experimental layout, with 12 irrigation sectors irrigated independently

2 by four sprinklers each. The irrigation treatments in each irrigation sector are

3 shown. The shaded areas are the experimental plots where alfalfa yield and soil

4 water content were measured. The location of the two access tubes for soil

5 water measurement installed in all the plots is shown in one of them.

6

7 Figure 2. Soil water content at different depths for the different irrigation

8 treatments during the experiment. For each soil layer, the horizontal dashed

9 lines indicate the soil water content at field capacity (upper) and wilting point

10 (lower). The three irrigation seasons (2012, 2013 and 2014) duration are

11 shown.

13 Figure 3. Regression analysis of seasonal average soil water content at 0-1.6 m

14 and the irrigation treatment at the three irrigation seasons. The horizontal

15 dashed line indicate the soil water content at field capacity (upper) and the

16 horizontal pointed line indicate the soil water content at wilting point (lower). The

17 error bars show the standard deviation. $\mathrm{CIR}_{\mathrm{t}}$ : theoretical crop irrigation

18 requirement.

20 Figure 4. Average seasonal intercepted photosynthetically active radiation

21 (PAR) by the alfalfa crop in the different irrigation treatments at the three 22 irrigation seasons. The error bars show the standard deviation. $\mathrm{CIR}_{\mathrm{t}}$ : theoretical crop irrigation requirement. 
1 Figure 5. Regression analysis of average seasonal plant height of alfalfa at

2 harvest and the irrigation treatment at the three irrigation seasons. $\mathrm{CIR}_{\mathrm{t}}$ :

3 theoretical crop irrigation requirement.

4

5 Figure 6. Regression analysis of seasonal forage yield of alfalfa and the 6 irrigation treatment at the three irrigation seasons. $\mathrm{CIR}_{\mathrm{t}}$ : theoretical crop 7 irrigation requirement.

9 Figure 7. Regression analysis of yield weighted average $\mathrm{N}$ content of the alfalfa 10 forage and the irrigation treatment at the three irrigation seasons. $C I R_{t}$ :

11 theoretical crop irrigation requirement.

12

13 Figure 8. Regression analysis of alfalfa forage $\mathrm{N}$ uptake and the irrigation 14 treatment at the three irrigation seasons. $\mathrm{CIR}_{\mathrm{t}}$ : theoretical crop irrigation 15 requirement.

17 Figure 9. Relationship of alfalfa forage yield and actual evapotranspiration 18 determined with the water balance $\left(E T_{w b}\right)$ at the three irrigation seasons.

20 Figure 10. Regression analysis of water use efficiency (WUE) of alfalfa and the 21 irrigation treatment at the three irrigation seasons. $\mathrm{CIR}_{\mathrm{t}}$ : theoretical crop 22 irrigation requirement. 


\section{Area around the}

experimental

sectors

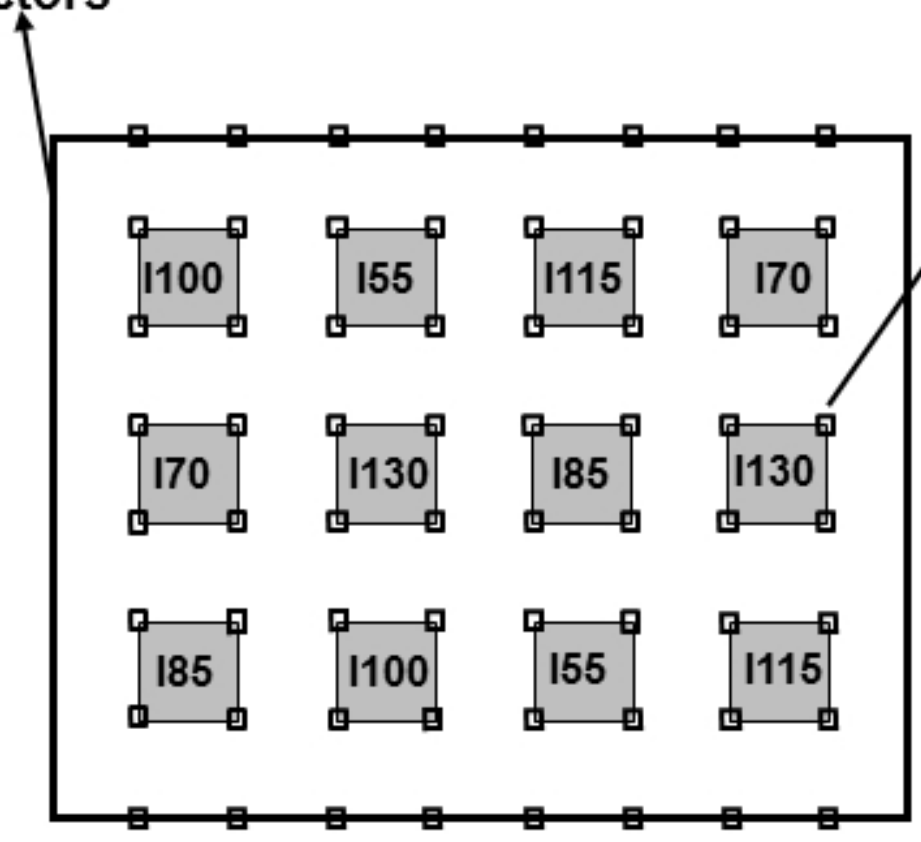

口 Sprinklers

Soil water measurement access tube 


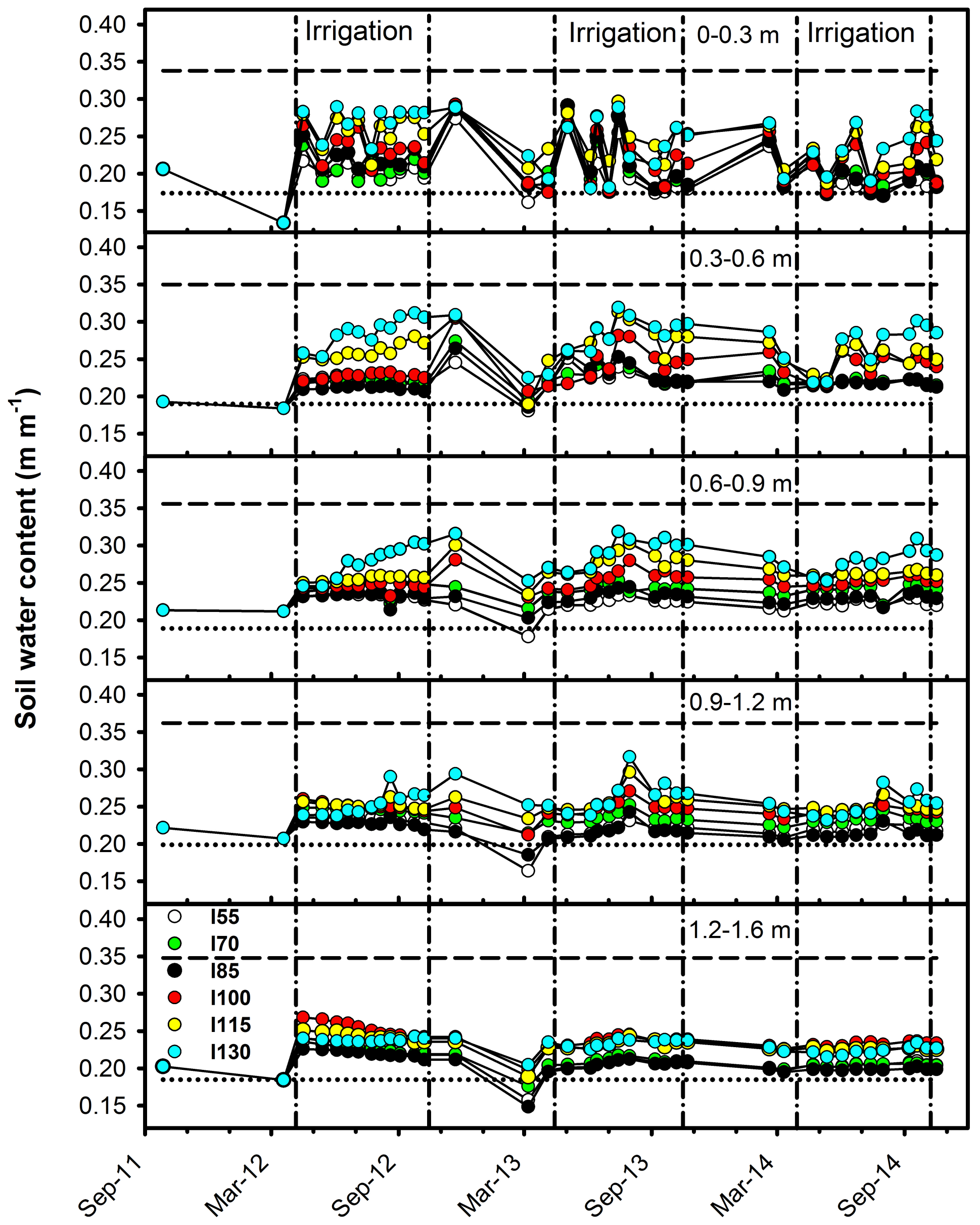




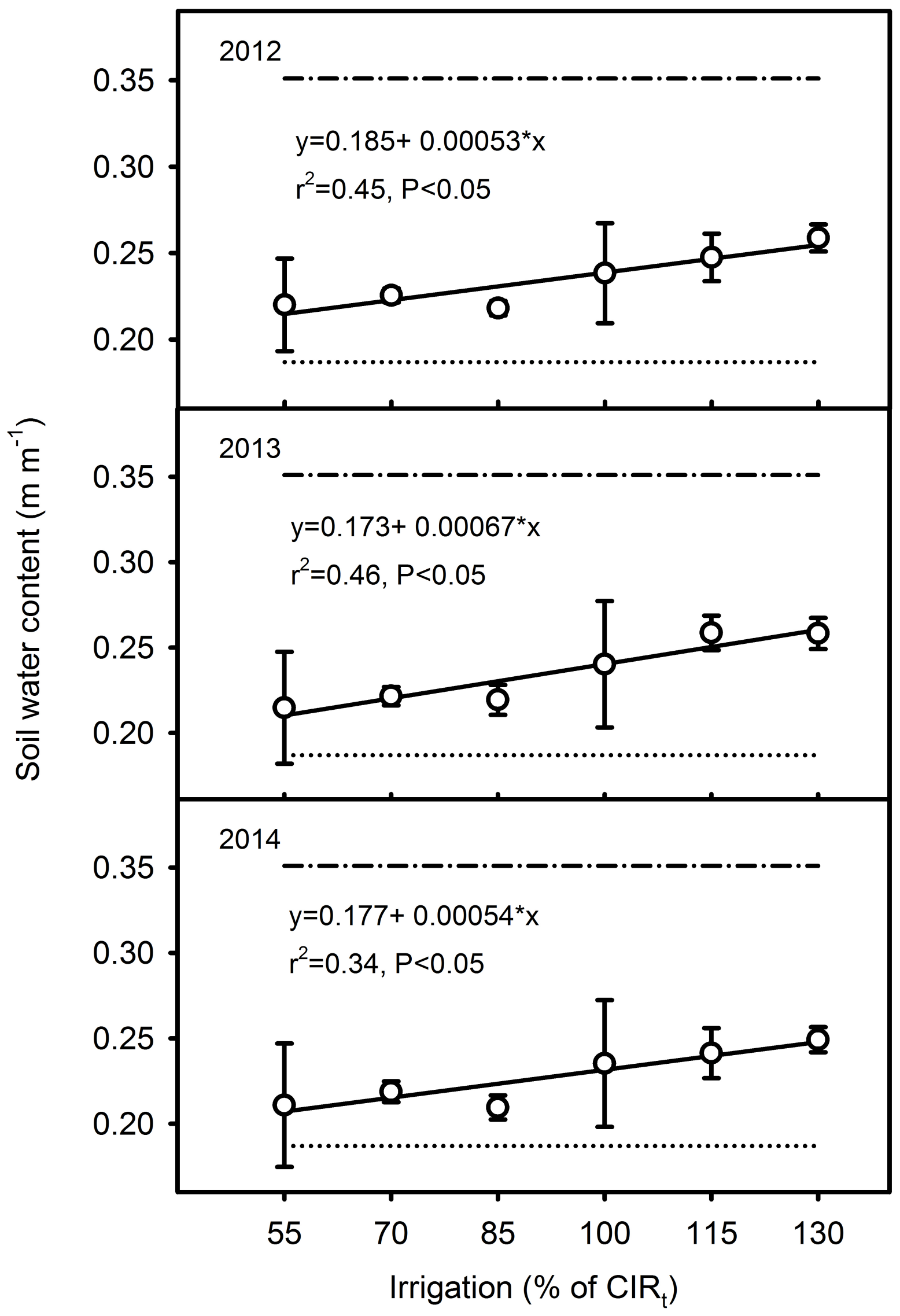




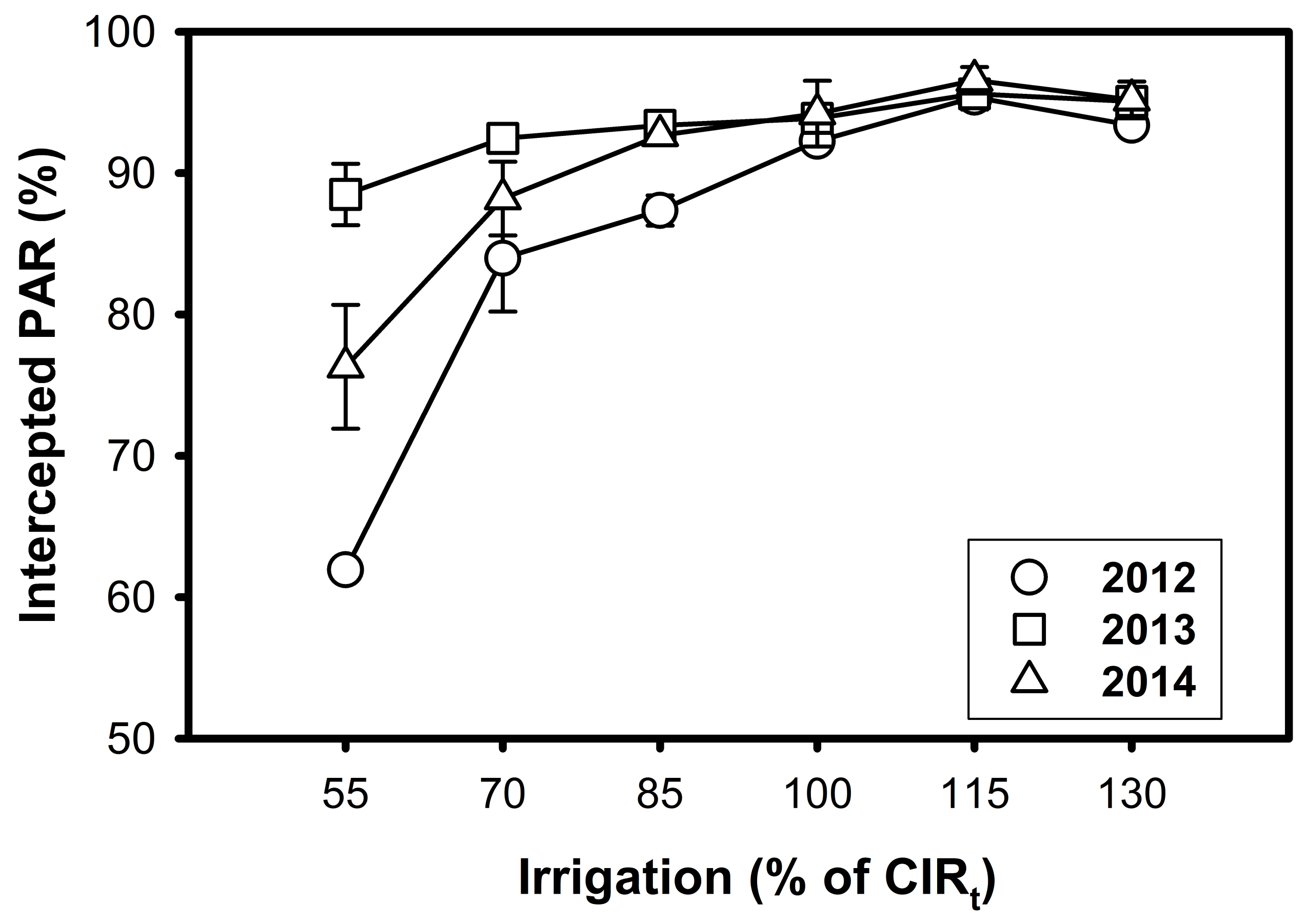




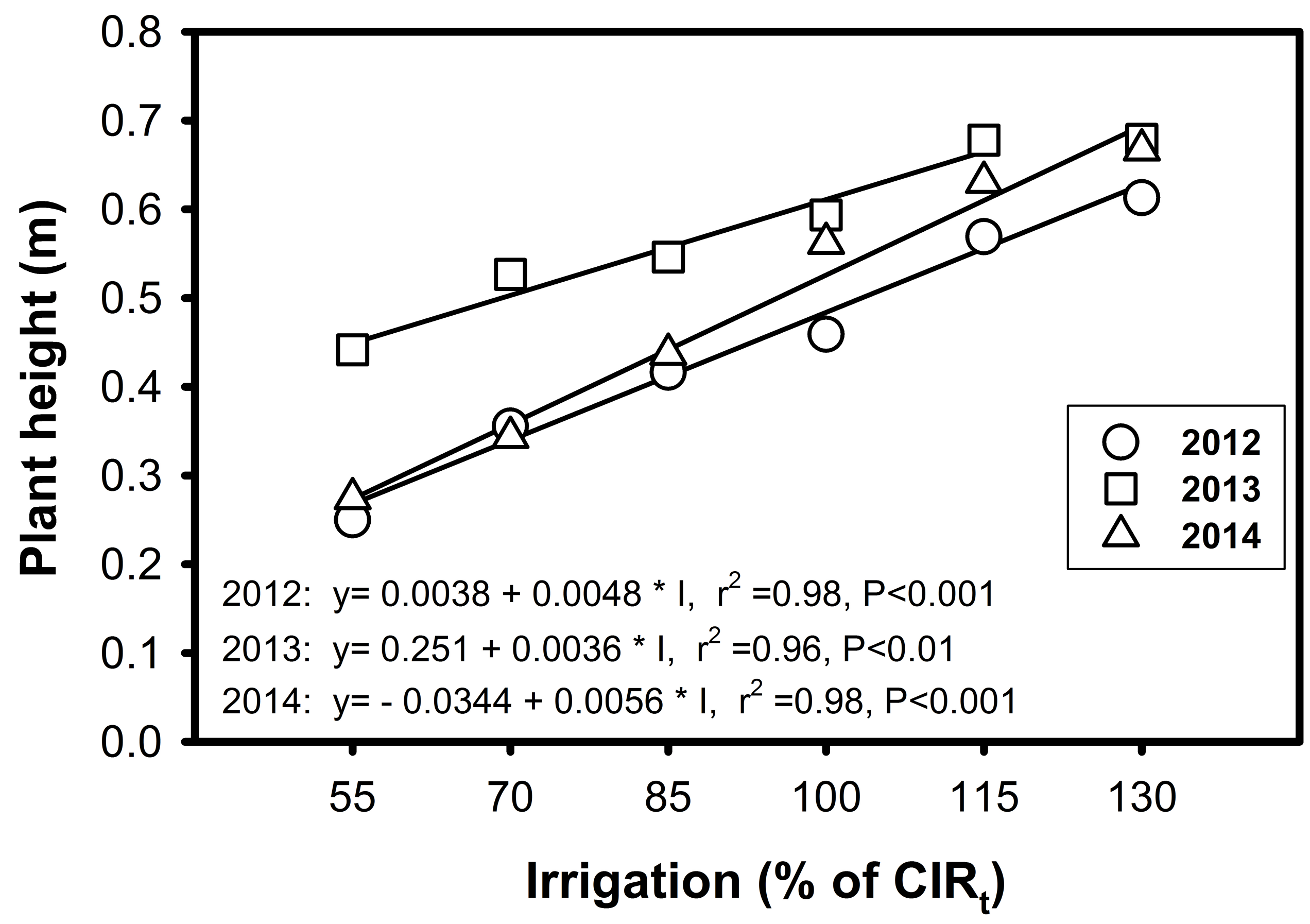




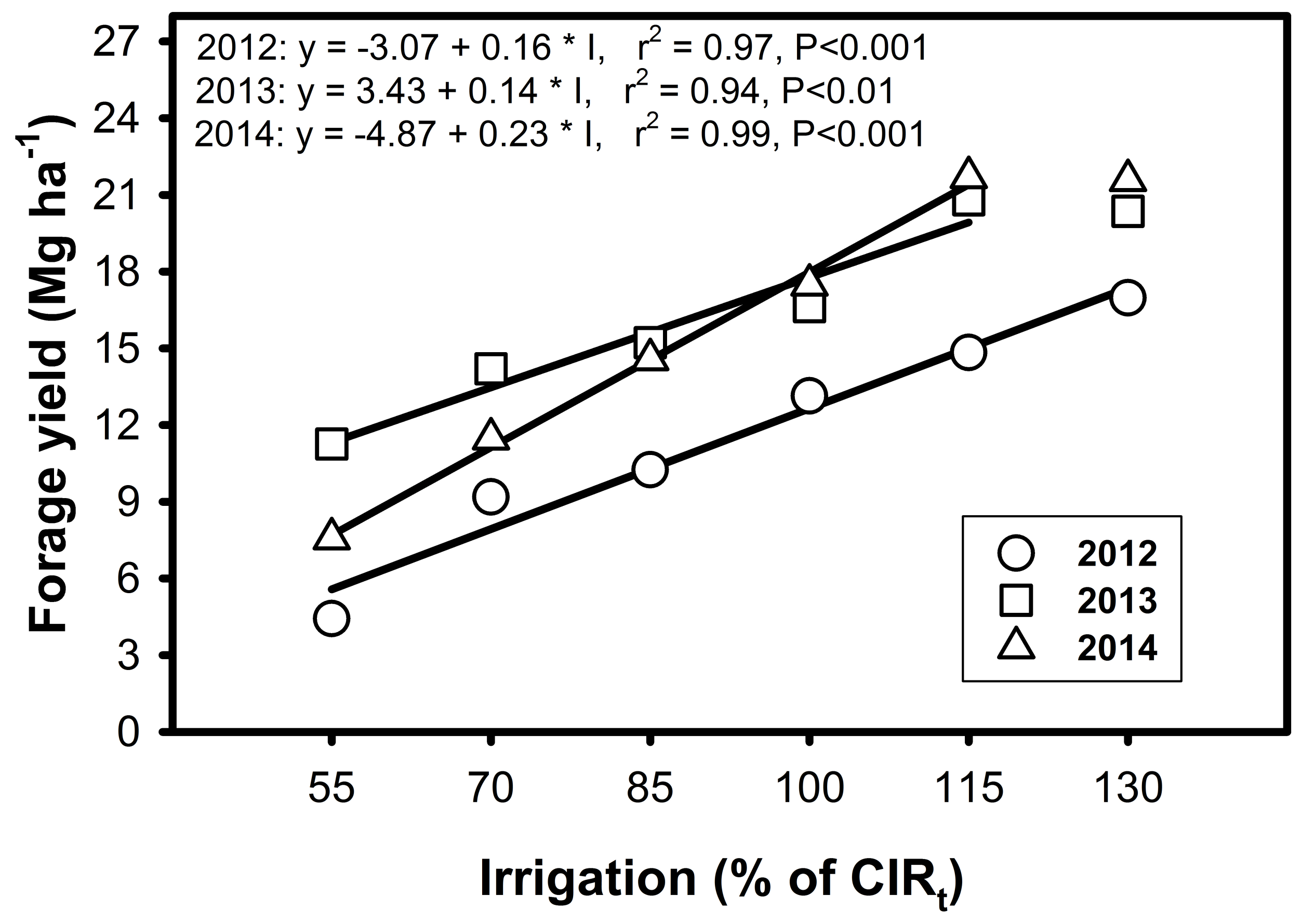




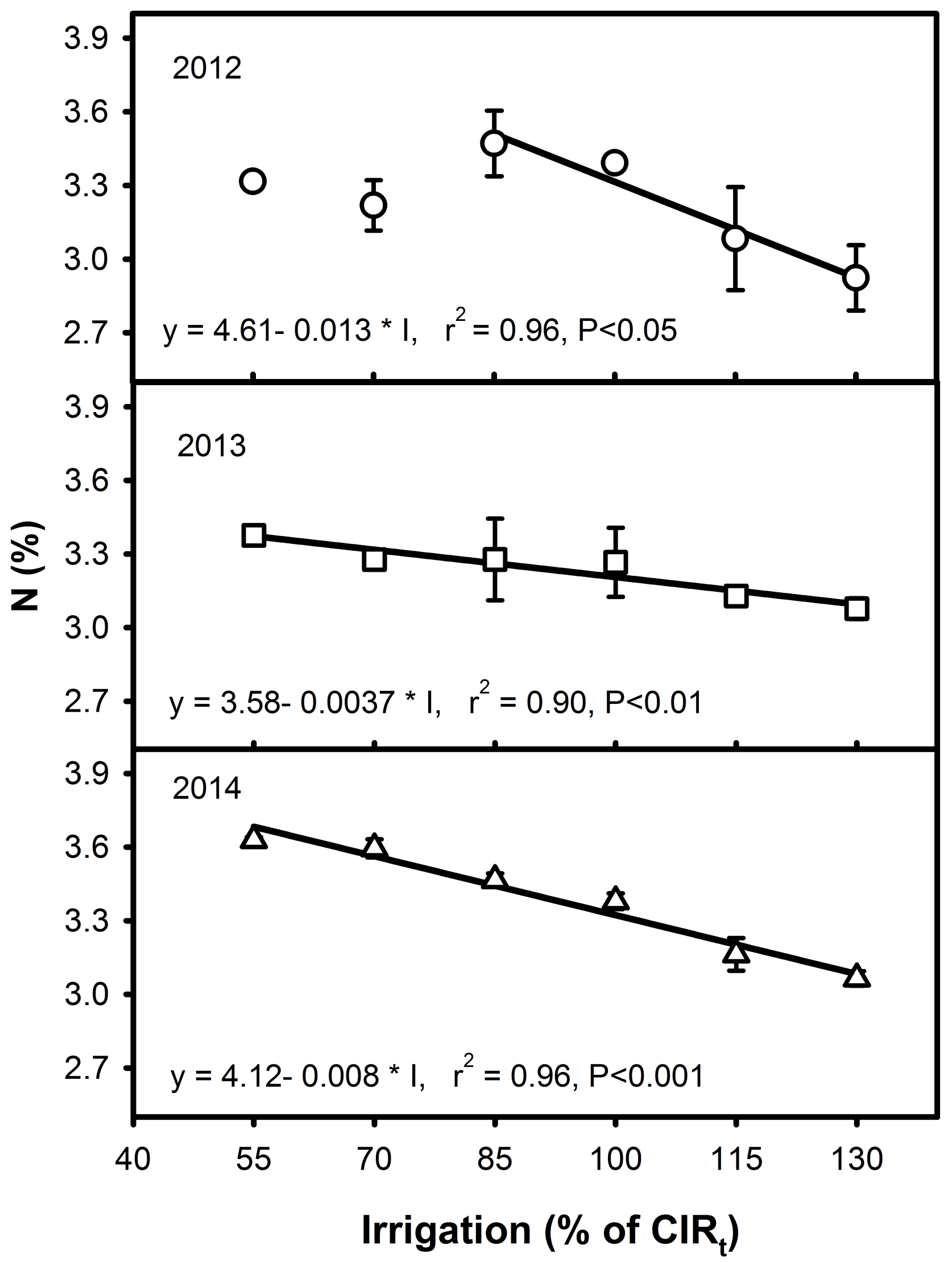




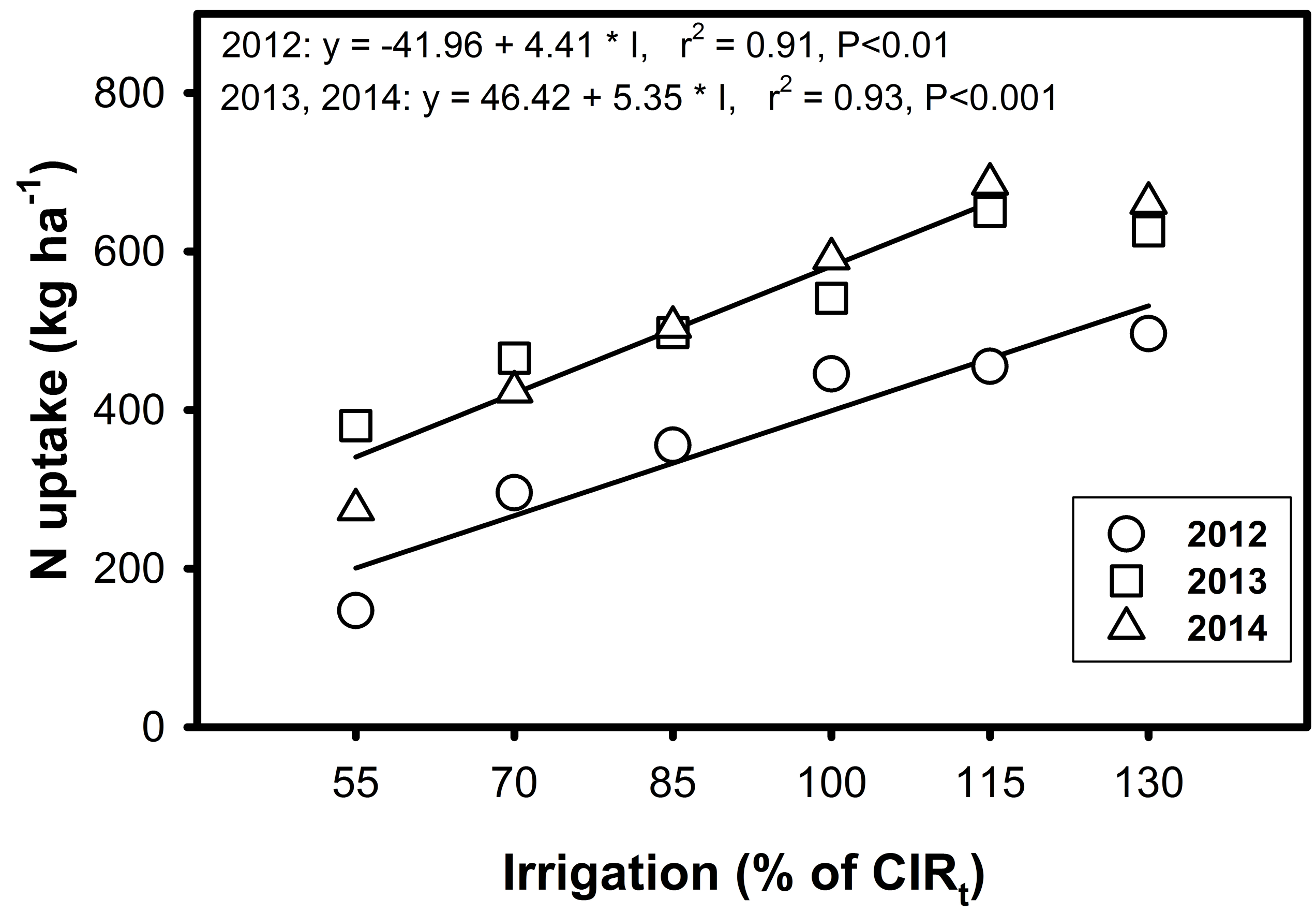




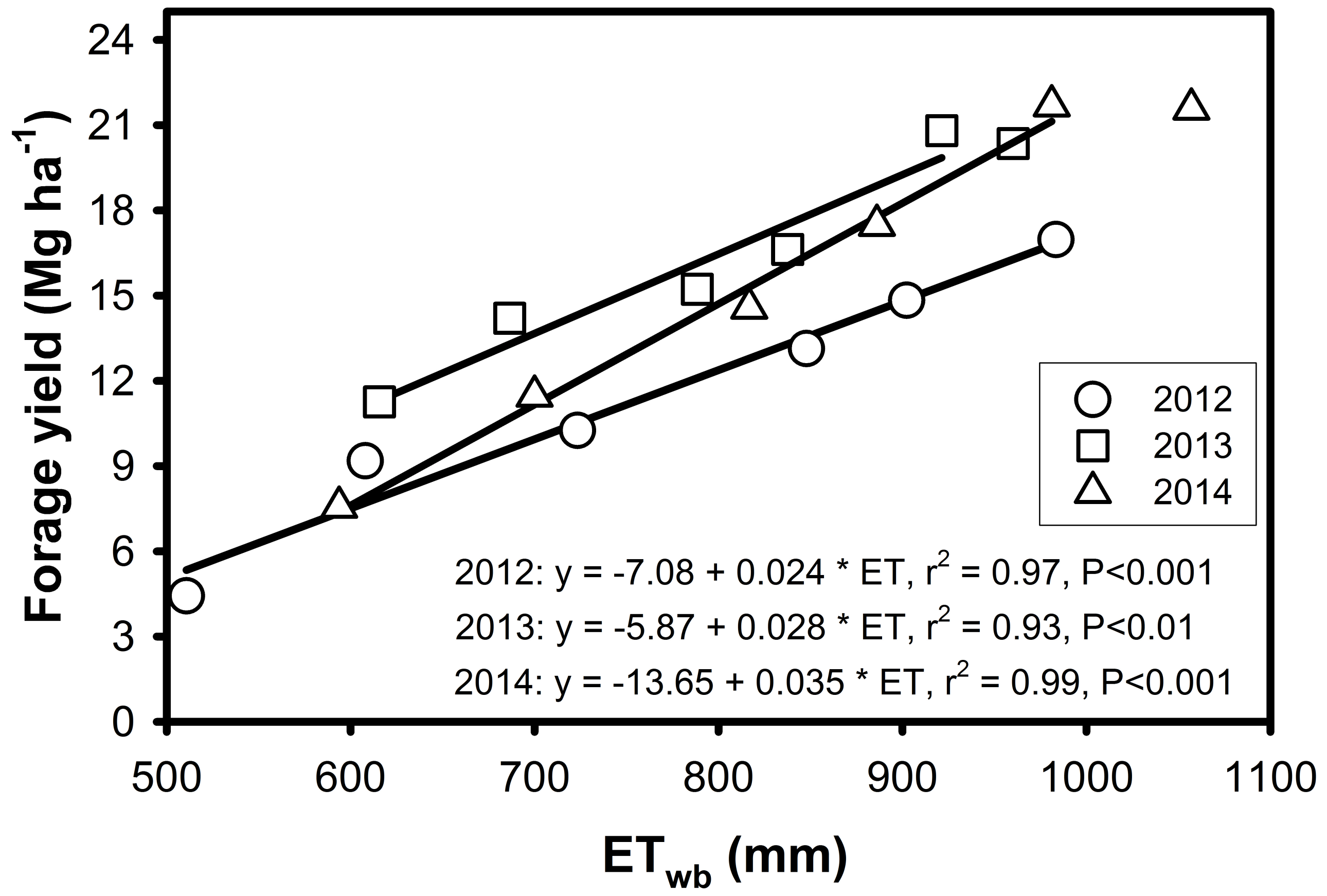




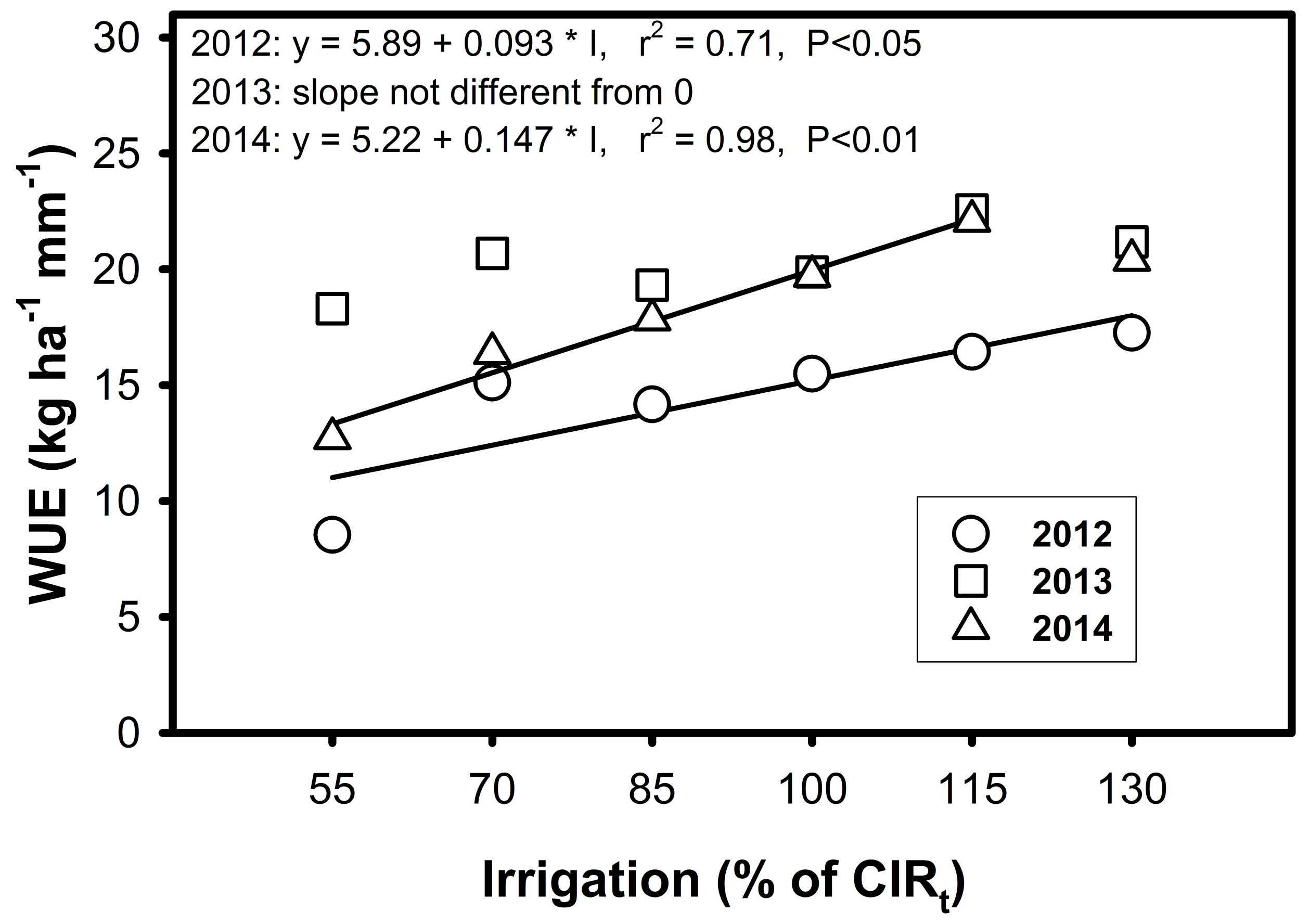


Table 1. Soil characteristics of the experimental field.

\begin{tabular}{|c|c|c|c|c|c|c|c|c|c|}
\hline Depth (m) & $\mathrm{pH}$ & C (\%) & $\mathrm{N}(\%)$ & $\mathrm{CaCO}_{3}(\%)$ & Sand (\%) & Silt (\%) & Clay (\%) & $\mathrm{FC}^{\mathrm{a}}\left(\mathrm{m} \mathrm{m}^{-1}\right)$ & $W P^{b}\left(\mathrm{~m} \mathrm{~m}^{-1}\right)$ \\
\hline $0.0-0.3$ & 8.2 & 1.04 & 0.12 & 36.0 & 21.3 & 51.1 & 27.6 & 0.338 & 0.174 \\
\hline $0.3-0.6$ & 8.3 & 0.71 & 0.10 & 36.0 & 19.4 & 49.7 & 30.9 & 0.350 & 0.190 \\
\hline $0.6-0.9$ & 8.2 & 0.54 & 0.08 & 35.0 & 14.5 & 54.6 & 30.9 & 0.356 & 0.189 \\
\hline $0.9-1.2$ & 8.0 & 0.48 & 0.07 & 34.0 & 14.0 & 53.3 & 32.7 & 0.362 & 0.199 \\
\hline $1.2-1.6$ & 8.1 & 0.45 & 0.07 & 36.0 & 17.2 & 52.5 & 30.3 & 0.348 & 0.185 \\
\hline
\end{tabular}

${ }^{\text {a }}$ FC, field capacity $(-0.033 \mathrm{MPa})$

${ }^{\mathrm{b}} \mathrm{WP}$, wilting point $(-1.5 \mathrm{MPa})$ 
Table 2. Average daily values of air temperature, wind speed and solar radiation, and cumulative daily values of reference evapotranspiration (ETo) and rainfall during the main period of alfalfa growth ( $1^{\text {st }}$ March $-15^{\text {th }}$ October) in the three crop seasons.

\begin{tabular}{cccccc}
\hline Year & Air temperature $\left(^{\circ} \mathrm{C}\right)$ & Wind speed $\left(\mathrm{m} \mathrm{s}^{-1}\right)$ & Radiation $\left(\mathrm{MJ} \mathrm{m}^{-2}\right)$ & ETo $(\mathrm{mm})$ & Rainfall $(\mathrm{mm})$ \\
\hline 2012 & 19.2 & 2.29 & 22.24 & 1138 & 148 \\
2013 & 17.9 & 2.33 & 21.08 & 1009 & 266 \\
2014 & 18.8 & 2.34 & 21.90 & 1079 & 182 \\
\hline
\end{tabular}


Table 3. Initial available soil water $(0-1.6 \mathrm{~m})$ and irrigation water applied to alfalfa in the different irrigation treatments in the crop seasons of 2012, 2013 and 2014.

\begin{tabular}{lrrrrrr}
\hline Treatment & \multicolumn{3}{c}{ Initial available soil water $(\mathrm{mm})$} & \multicolumn{3}{c}{ Irrigation water applied $(\mathrm{mm})$} \\
\cline { 2 - 7 } & 2012 & 2013 & 2014 & 2012 & 2013 & 2014 \\
\hline 155 & 10 & -28 & 48 & 434 & 370 & 400 \\
170 & 10 & 16 & 62 & 551 & 424 & 506 \\
185 & 10 & -9 & 48 & 669 & 541 & 628 \\
$\mathrm{I} 100$ & 10 & 29 & 91 & 786 & 598 & 701 \\
$\mathrm{I} 115$ & 10 & 35 & 103 & 904 & 684 & 795 \\
$\mathrm{I} 130$ & 10 & 66 & 115 & 1023 & 735 & 888 \\
\hline
\end{tabular}


Table 4. Average values of irrigation applied and wind speed during the irrigation events in the different irrigation treatments and crop seasons (2012, 2013 and 2014).

\begin{tabular}{lrrrrrr}
\hline \multirow{2}{*}{ Treatment } & \multicolumn{3}{c}{ Mean depth per irrigation $(\mathrm{mm})$} & \multicolumn{3}{c}{ Mean wind speed $\left(\mathrm{m} \mathrm{s}^{-1}\right)$} \\
\cline { 2 - 7 } & 2012 & 2013 & 2014 & 2012 & 2013 & 2014 \\
\hline 155 & 25 & 14 & 16 & 2.3 & 2.3 & 2.5 \\
170 & 21 & 15 & 17 & 2.5 & 2.5 & 2.5 \\
185 & 24 & 17 & 19 & 2.5 & 2.5 & 2.6 \\
1100 & 23 & 18 & 21 & 2.5 & 2.5 & 2.5 \\
1115 & 25 & 20 & 23 & 2.5 & 2.5 & 2.7 \\
1130 & 28 & 22 & 26 & 2.6 & 2.6 & 2.7 \\
\hline
\end{tabular}


Table 5. Average values of alfalfa forage yield for the different irrigation treatments at each harvest cycle of alfalfa in the three years of the experiment.

\begin{tabular}{|c|c|c|c|c|c|c|c|}
\hline \multirow[t]{2}{*}{ Year } & \multirow{2}{*}{$\begin{array}{l}\text { Harvest } \\
\text { cycle }\end{array}$} & \multicolumn{6}{|c|}{ Forage yield $\left(\mathrm{Mg} \mathrm{ha}^{-1}\right)$} \\
\hline & & 155 & 170 & 185 & 1100 & 1115 & 1130 \\
\hline \multirow{7}{*}{2012} & 1 & 2.08 & 3.25 & 2.62 & 2.88 & 3.04 & 3.42 \\
\hline & 2 & 0.76 & 1.68 & 2.38 & 3.13 & 3.28 & 3.58 \\
\hline & 3 & 0.58 & 1.53 & 1.95 & 2.67 & 2.82 & 3.44 \\
\hline & 4 & 0.18 & 0.80 & 1.13 & 1.73 & 2.32 & 2.99 \\
\hline & 5 & 0.50 & 1.26 & 1.57 & 2.03 & 2.42 & 2.55 \\
\hline & 6 & 0.32 & 0.66 & 0.59 & 0.68 & 0.96 & 0.99 \\
\hline & All & 4.43 & 9.19 & 10.25 & 13.14 & 14.84 & 16.97 \\
\hline \multirow[t]{7}{*}{2013} & 1 & 1.38 & 2.08 & 1.96 & 2.06 & 2.97 & 3.04 \\
\hline & 2 & 3.76 & 3.92 & 3.79 & 3.70 & 4.16 & 3.91 \\
\hline & 3 & 2.25 & 2.92 & 2.85 & 3.24 & 3.91 & 3.73 \\
\hline & 4 & 2.38 & 2.61 & 3.57 & 3.46 & 4.41 & 3.99 \\
\hline & 5 & 0.74 & 1.58 & 1.66 & 2.45 & 3.32 & 3.38 \\
\hline & 6 & 0.75 & 1.09 & 1.39 & 1.71 & 2.03 & 2.29 \\
\hline & All & 11.26 & 14.20 & 15.22 & 16.63 & 20.81 & 20.35 \\
\hline \multirow[t]{7}{*}{2014} & 1 & 1.68 & 2.03 & 2.24 & 2.18 & 2.95 & 3.01 \\
\hline & 2 & 1.61 & 2.08 & 2.43 & 2.94 & 4.03 & 3.89 \\
\hline & 3 & 1.40 & 2.26 & 2.89 & 3.66 & 4.17 & 4.09 \\
\hline & 4 & 1.01 & 1.66 & 2.32 & 3.00 & 4.37 & 4.62 \\
\hline & 5 & 1.15 & 1.96 & 2.69 & 3.58 & 3.76 & 3.48 \\
\hline & 6 & 0.72 & 1.48 & 2.00 & 2.11 & 2.40 & 2.47 \\
\hline & All & 7.56 & 11.47 & 14.56 & 17.48 & 21.69 & 21.57 \\
\hline All & & 23.25 & 34.86 & 40.03 & 47.25 & 57.34 & 58.89 \\
\hline
\end{tabular}


Table 6. Calculated evapotranspiration from the water balance (ET wb) and comparison with the theoretical alfalfa

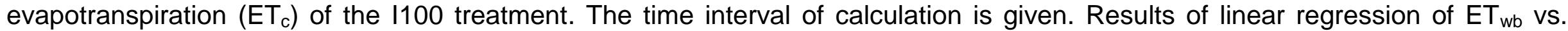
irrigation treatment for each year are shown.

\begin{tabular}{lrrrrrr}
\hline Treatment & \multicolumn{3}{c}{$\mathrm{ET}_{\mathrm{wb}}(\mathrm{mm})$} & \multicolumn{3}{c}{$\mathrm{ET}_{\mathrm{wb}} / \mathrm{ET}_{\mathrm{c}}$} \\
\cline { 2 - 7 } & $2012^{\mathrm{a}}$ & $2013^{\mathrm{b}}$ & $2014^{\mathrm{C}}$ & 2012 & 2013 & 2014 \\
\hline $\mathrm{I} 55$ & 511 & 616 & 594 & 0.59 & 0.75 & 0.65 \\
$\mathrm{I} 70$ & 608 & 687 & 700 & 0.71 & 0.83 & 0.76 \\
$\mathrm{I} 85$ & 723 & 788 & 817 & 0.84 & 0.96 & 0.89 \\
$\mathrm{I} 100$ & 848 & 838 & 886 & 0.98 & 1.02 & 0.97 \\
$\mathrm{I} 115$ & 902 & 921 & 981 & 1.05 & 1.12 & 1.07 \\
$\mathrm{I} 130$ & 983 & 960 & 1057 & 1.14 & 1.17 & 1.15 \\
\hline Regression & & & & & \\
Slope significance & $\mathrm{P}<0.001$ & $\mathrm{P}<0.001$ & $\mathrm{P}<0.001$ & & & \\
$r^{2}$ & 0.99 & 0.99 & 0.99 & & & \\
\hline
\end{tabular}

a 19 March - 8 October

b 7 March - 23 October

c 18 February -3 October 